\title{
5-Hydroxytryptamine Induces a Protein Kinase A/ Mitogen-Activated Protein Kinase-Mediated and Macromolecular Synthesis-Dependent Late Phase of Long-Term Potentiation in the Amygdala
}

\author{
Yan-You Huang ${ }^{2}$ and Eric R. Kandel ${ }^{1,2,3,4}$ \\ ${ }^{1}$ Kavli Institute for Brain Science, ${ }^{2}$ Center for Neurobiology and Behavior of the College of Physicians and Surgeons of Columbia University, ${ }^{3}$ New York State \\ Psychiatric Institute, and ${ }^{4}$ Howard Hughes Medical Institute, Columbia University, New York, New York 10032
}

\begin{abstract}
The amygdala is a critical site for the acquisition of learned fear memory in mammals, and the formation and long-term maintenance of fear memories are thought to be associated with changes of synaptic strength in the amygdala. Here we report that serotonin (5hydroxytryptamine; 5-HT), a modulatory neurotransmitter known to be linked to learned fearful and emotional behavior, has dual effects on excitatory synaptic transmission in the basolateral amygdala. There is an early depression of synaptic transmission lasting 30-50 min, mediated by 5- $\mathrm{HT}_{1 \mathrm{~A}}$, and a late, long-lasting facilitation lasting $>5 \mathrm{~h}$ in slice recordings, mediated by the 5 - $\mathrm{HT}_{4}$ receptor. 5-HT late phase long-term potentiation (L-LTP) is blocked by inhibitors of either protein kinase A (PKA) and/or mitogen-activated kinase (MAPK) and requires new protein synthesis and gene transcription. Moreover, the 5-HT-induced L-LTP in neurons of amygdala is blocked by the actin inhibitor cytochalasin D, suggesting that 5-HT stimulates a cytoskeletal rearrangement. These results show, for the first time, that 5-HT can produce long-lasting facilitation of synaptic transmission in the amygdala and provides evidence for the possible synaptic role of 5-HT in long-term memory for learned fear.
\end{abstract}

Key words: serotonin; amygdala; protein; protein kinase; cytoskeleton; L-LTP

\section{Introduction}

The basolateral amygdala complex (which contains the lateral, basolateral, and basomedial nuclei) is thought to be critical for the formation and storage of memory for learned fear (Amorapanth et al., 2000; LeDoux, 2000; Maren, 2003, 2005). Fear conditioning induces long-term facilitation of synaptic transmission in amygdala that is similar to the properties of longterm potentiation (LTP) induced by electrical stimulation (McKernan and Shinnick-Gallagher, 1997; Rogan et al., 1997, 2005). Moreover, preestablishment of fear conditioning in animals occludes subsequent LTP induced by electrical tetanus in amygdala (Tsvetkov et al., 2002; Schroeder and ShinnickGallagher, 2004, 2005). These results suggest that fear conditioning and LTP in the amygdala may share aspects of a common synaptic mechanism.

Serotonin (5-HT) is known to be a modulatory neurotransmitter linked to emotional behavior and anxiety (Griebel, 1995;

Received Sept. 8, 2006; revised Jan. 30, 2007; accepted Jan. 30, 2007.

This work was supported by the Howard Hughes Medical Institute, the New York State Psychiatric Institute, National Institute of Mental Health Grant MH50733, and a grant from National Institutes of Health Program Project on Amygdala and Anxiety States (to E.R.K.). We thank Michael Rogan for a critical reading of this manuscript and helpful comments.

Correspondence should be addressed to Eric R. Kandel, Columbia University, 722 West 168th Street, New York, NY 10032. E-mail: ERK5@columbia.edu.

DOl:10.1523/JNEUROSCI.3908-06.2007

Copyright $\odot 2007$ Society for Neuroscience $\quad$ 0270-6474/07/273111-09\$15.00/0
Graeff et al., 1997; Lucki, 1998; Gordon and Hen, 2004). Indeed, the amygdala is innervated richly by 5 -HT-containing fiber originating from the dorsal raphe nucleus (Azmitia and Segal, 1978; Azmitia and Gannon, 1986; Ma et al., 1991). Changes of 5-HT levels and 5-HT functions in amygdala are associated with the dysfunction of emotional behavior (Graeff et al., 1997; Hariri et al., 2002; McGregor et al., 2003; Keele, 2005). The critical role of 5-HT in fear memory and anxiety raises a question: what is the role of 5-HT on synaptic plasticity in amygdala? The short-lasting effect of 5-HT on the excitatory synaptic transmission in the basolateral subdivision (BL) has been reported. It has been shown that bath application of 5-HT cause a reversible depression of EPSPs in the basolateral amygdala that lasts $\sim 1$ h (Cheng et al., 1998; Wang et al., 1999). In contrast, nothing is known about the long-term effect $(>1 \mathrm{~h})$ of 5 -HT on synaptic transmission in amygdala.

These long-term effects are potentially very important, because one of the characteristic features of conditioned fear is persistence (Schafe et al., 2001; Gale et al., 2004). In previous studies we found that the late phase of LTP (L-LTP) in lateral amygdala (LA) requires protein kinase A-mediated (PKAmediated) new protein synthesis, and the expression of L-LTP in lateral amygdala is associated with increased phosphorylation of cAMP response element-binding (CREB) proteins (Huang et al., 2000). In the present study we have extended the analysis of L-LTP in the BL of amygdala by focusing on 5-HT-mediated 
modulation. BL is an important site of plasticity in fear conditioning. In contrast to LA, BL is critical for the expression, but not the acquisition, of learned fear (Anglada-Figueroa and Quirk, 2005; Corcoran and Quirk, 2007). Projections from LA to BL mediate the ability of a conditioned stimulus to reinforce the acquisition of new responses (Amorapanth et al., 2000). Changes of 5-HT levels during memory for learned fear have been detected in the BL (Kawahara et al., 1993; Macedo et al., 2004, 2005; Yokoyama et al., 2005). We therefore asked, what is the long-term effect of 5-HT ( $>1 \mathrm{~h}$ ) on excitatory synaptic transmission in BL? Which 5-HT receptor is responsible for this long-term effect? Is the long-term effect mediated by the PKA/mitogen-activated kinase (MAPK) signaling pathway? Is the long-term effect of 5-HT dependent on new protein synthesis, gene transcription, and cytoskeletal remodeling of neurons?

\section{Materials and Methods}

C57/B6 mice (6-12 weeks old) were decapitated quickly, the whole brain was placed in ice-cold artificial CSF (ACSF), and a block containing the amygdala was taken. Coronal section of slices ( $400 \mu \mathrm{m}$; from -1.4 to -1.9 $\mathrm{mm}$ bregma) were cut and transferred to an interface chamber (Fine Science Tools, Foster City, CA). Slices were submerged fully and perfused constantly with ACSF at a rate of $2 \mathrm{ml} / \mathrm{min}$ and bubbled with $95 \% \mathrm{O}_{2} / 5 \%$ $\mathrm{CO}_{2}$. The composition of ACSF was as follows (in mM): $124 \mathrm{NaCl}, 1.2$ $\mathrm{MgSO}_{4}, 4 \mathrm{KCl}, 1.0 \mathrm{NaH}_{2} \mathrm{PO}_{4}, 2 \mathrm{CaCl}_{2}, 26 \mathrm{NaHCO}_{3}$, and 10 D-glucose. In some experiments GABAergic antagonist picrotoxin $(10 \mu \mathrm{M})$ was present in the perfusion solution from the beginning of slice perfusion and throughout the experiments. In these experiments $4 \mathrm{~mm} \mathrm{MgSO}_{4}$ and 4 $\mathrm{mM} \mathrm{CaCl}_{2}$ were used to reduce the epilepsy. The temperature of the slices was maintained at $27^{\circ} \mathrm{C}$. Experiments were started $2-3 \mathrm{~h}$ after slice dissection.

Extracellular recordings were made by using ACSF-filled glass electrodes $(1-3 \mathrm{M})$. The recording electrode was placed in the BL of amygdala. The stimulation electrode was placed in the LA to stimulate the LA-BL circuitry (see Fig 1) (Cheng et al., 1998; Wang et al., 1999; Lin et al., 2000; Rammes et al., 2000). Stimuli were delivered $1 / \mathrm{min}(0.017 \mathrm{~Hz} ; 0.05 \mathrm{~ms}$ pulse duration) through concentric bipolar stainless steel electrodes (25 $\mu \mathrm{m}$ wire diameter, CBBRC75, FHC, Bowdoinham, ME). The stimulation intensity was adjusted to evoke the field potentials, which were $\sim 50 \%$ of maximal amplitude. To achieve 5-HT LTP, we fully submerged the slices, and 5-HT (100-300 $\mu \mathrm{M})$ was perfused for $25 \mathrm{~min}(50 \mathrm{ml})$ at a constant speed of $2 \mathrm{ml} / \mathrm{min}$. Field potentials were amplified with an Axoclamp-2A amplifier (Molecular Devices, Foster City, CA), and the signals were digitized with the Digidata 1320A data acquisition system. On-line and off-line data acquisition and analysis were performed with Clampex version 9.0 (Molecular Devices). Peak amplitudes of field potentials were measured and plotted. Baseline values were acquired over a period of $30 \mathrm{~min}$ before the application of 5-HT. To elicit LTP by electrical stimulation, we used four groups of $100 \mathrm{~Hz}$ of tetanus (each group containing two trains of $100 \mathrm{~Hz}, 1 \mathrm{~s}$ stimulation in 10 s intervals; the pulse duration was $0.1 \mathrm{~ms}$ during tetanus) $3 \mathrm{~min}$ apart. Any changes in synaptic strength were expressed relative to normalized baseline (mean \pm SEM). Statistical comparisons were performed by using Student's $t$ test and ANOVA.

When used, pharmacological agents were applied via the bath medium. The following drugs were made in water or in DMSO, stored as concentrated stock solution, and diluted 1000-fold when applied to the perfusion solution: $(9 S, 10 R, 12 R)-2,3,9,10,11,12$-hexahydro-10-hydroxy9-methyl-1-oxo-9,12-epoxy- ${ }^{1} H$-diindolo-[1,2,3-fg:3' $2^{\prime}, 1^{\prime}$-kl] pyrrolo[3,4i] [1,6]benzodiazocine-10-carboxylic acid hexyl ester (KT5720; dissolved in DMSO; Biomol, Plymouth Meeting, PA), 1,4-diamino-2,3-dicyano-1,4bis(2-aminophenylthio)butadiene (U0126; in DMSO; Biomol), anisomycin (in water; Sigma, St. Louis, MO), D-(-)-2-amino-5-phosphonopentanotic acid (D-APV; in water; Sigma), actinomycin D (ACTD; in DMSO; Sigma), 1-(2-methoxyphenyl)-4-[4-(2-phthalimido)butyl] piperazine (NAN-190; in DMSO; Sigma), zimelidine (in water; Sigma), 1-(4-amino-5-chloro-2methoxyphenyl)-3-[1-butyl-4-piperidinyl]-1-propanone hydrochloride
(RS 67333; in DMSO; Tocris, Bristol, UK), 3-(piperidin-1-yl)propyl 4-amino-5-chloro-2-methoxybenzoate hydrochloride (RS 23597-190; in water; Tocris), and cytochalasin D (in DMSO; Sigma). 5-HT (Sigma) was freshly dissolved in ACSF just before application in each experiment. The final concentration of DMSO was $0.1 \%$. In each control experiment $0.1 \%$ DMSO was used; no effect on baseline recording was found.

\section{Results}

\section{5-HT has different short-term and long-term effects on synaptic plasticity in amygdala}

The pathway between the LA and the BL is a critical part of the intra-amygdala circuit (Stefanacci et al., 1992). This pathway has been used previously for the analysis of synaptic plasticity in the BL of amygdala (Cheng et al., 1998; Wang et al., 1999; Lin et al., 2000; Rammes et al., 2000; DeBock et al., 2003). Orthodromic stimuli applied to the LA reliably elicited a negative field potential in the BL (Fig. 1 A,B).This field potential follows $50 \mathrm{~Hz}$ of stimulation reliably, without failure, and is blocked completely by the glutamate antagonist CNQX (Fig $1 B$ ), indicating that this field potential reflects monosynaptic glutamatergic transmission (Huang et al., 2000; Rammes et al., 2000). This field potential is stable for many hours and therefore allows for the analysis of L-LTP $(>3 \mathrm{~h})$ in the BL of amygdala.

We first examined the effect of 5-HT on synaptic transmission in the BL nucleus. Consistent with the early reports (Cheng et al., 1998; Wang et al., 1999), the bath application of 5-HT induced a synaptic depression in the BL. The synaptic depression started $\sim 10 \mathrm{~min}$ after 5 -HT application $(300 \mu \mathrm{M} ; 25 \mathrm{~min})$ and lasted $\sim 30-50 \mathrm{~min}$. By $30 \mathrm{~min}$ after exposure to 5-HT the amplitude of field potential was reduced significantly $(67 \pm 6 \%$; $n=9)$. However, to our surprise, we found that the depression was followed by a long-lasting facilitation of synaptic transmission. This increase in the amplitude of field potential emerges $\sim 1 \mathrm{~h}$ after the application of 5-HT and lasts for at least $5 \mathrm{~h}$ in slices ( $1 \mathrm{~h}, 129 \pm$ $7 \%$; 3 h, $153 \pm 8 \% ; 5$ h, $152 \pm 10 \% ; n=9$ ) (Fig. $1 C$ ). In control experiments baseline recordings were stable for up to $5 \mathrm{~h}(5 \mathrm{~h}$, $97 \pm 12 \% ; n=5 ; p<0.01$; Student's $t$ test). The 5 -HT induces L-LTP in a dose-dependent manner. Application of $50 \mu \mathrm{M} 5$-HT induced only a weak potentiation of $109 \pm 7 \%(n=5 ; 3.5 \mathrm{~h}$ after 5 -HT). Doses of 100 and $200 \mu \mathrm{M}$ increased the late synaptic potentiation to $131 \pm 5 \%(n=6)$ and $144 \pm 10 \%(n=5 ; 3.5 \mathrm{~h}$ after 5 -HT), whereas $300 \mu \mathrm{M} 5$-HT produced a maximal potentiation of $159 \pm 6 \%(n=12 ; 3.5 \mathrm{~h}$ after $5-\mathrm{HT})$. The dose-response histograms of early synaptic depression (E-depression; $30 \mathrm{~min}$ after the application of 5-HT) and late synaptic potentiation (3.5 $\mathrm{h}$ after the application of 5-HT) are shown in Figure $1 D$. ANOVA revealed that E-depression measured $30 \mathrm{~min}$ after 5 -HT and L-LTP measured $3.5 \mathrm{~h}$ after 5 -HT were significantly different between groups [E-depression, $F_{(3,24)}=6.8(p<0.01)$; L-LTP, $F_{(3,24)}=12(p<0.01)$; ANOVA].

The 5-HT receptor can be divided into several subtypes (Barnes and Sharp, 1999). We next asked which subreceptor is involved in the synaptic potentiation. Because the $5-\mathrm{HT}_{4}$ receptor is coupled positively with the CAMP/PKA signaling pathway (Eglen et al., 1995; Torres et al., 1996; Barnes and Sharp, 1999; Heine et al., 2002; Svenningsson et al., 2002) and we earlier had found PKA signaling cascades to be involved critically in L-LTP of amygdala (Huang and Kandel, 1998; Huang et al., 2000, 2005), we asked whether 5-HT-induced L-LTP can be blocked by the $5-\mathrm{HT}_{4}$ receptor antagonist RS 23597. We found that, in the presence of RS $23597(50 \mu \mathrm{M})$, the depression produced by 5-HT was not affected but that the long-term synaptic facilitation was abolished completely [5-HT, $170 \pm 6 \%(n=6)$; 5 -HT plus RS 23597, 
A

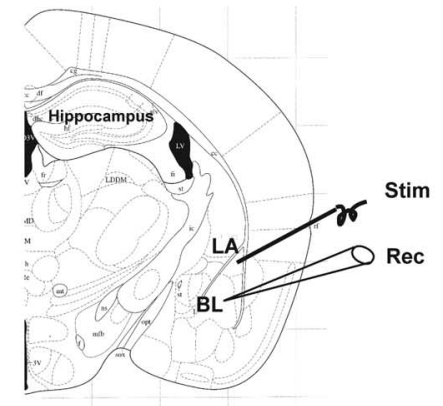

B

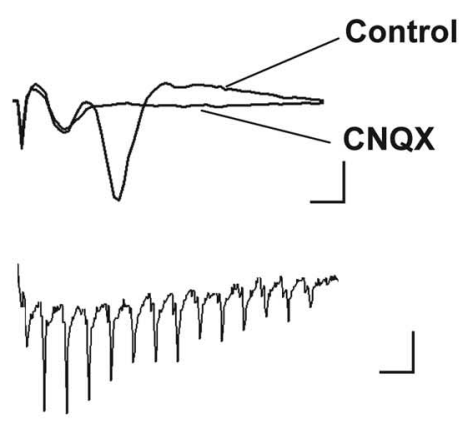

C

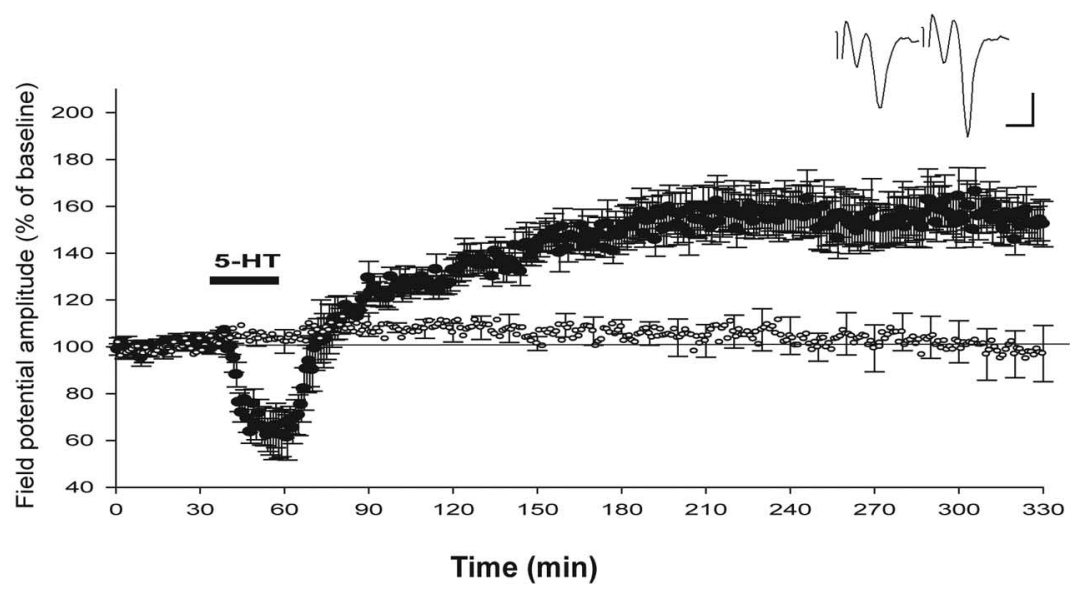

D1

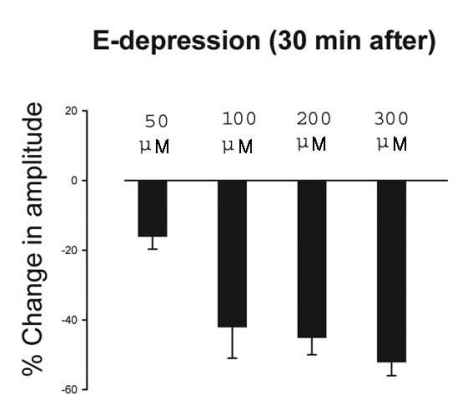

D2

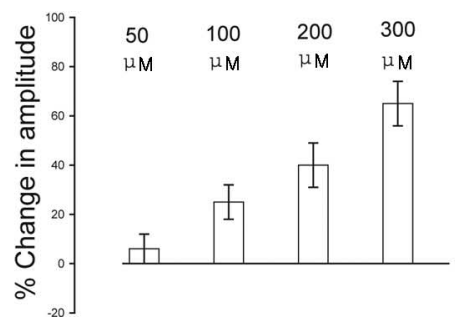

Figure 1. 5-HT induces L-LTP in the BL of amygdala. $A$, Schematic illustration of stimulating and recording sites in a coronal brain slice. The stimulating electrode (Stim) was placed in the LA of amygdala. The recording electrode (Rec) was placed in the BL of amygdala. $\boldsymbol{B}$, Top, The synaptic potential recorded from the $L A-B L$ pathway is blocked completely by the glutamate antagonist CNQX. Calibration: $0.5 \mathrm{mV}, 3 \mathrm{~ms}$. $\boldsymbol{B}$, Bottom, The synaptic potential follows a $50 \mathrm{~Hz}$ tetanus in a one-for-one manner without failure. Calibration: $0.5 \mathrm{mV}, 10 \mathrm{~ms}$. C, Bath application of $5-\mathrm{HT}(300 \mu \mathrm{m})$ induces an early phase of synaptic depression, followed by a late phase of long-lasting synaptic potentiation in the BL. 5-HT, Filled circles; baseline control, unfilled circles. Representative field potentials $10 \mathrm{~min}$ before and $5 \mathrm{~h}$ after the application of $5-\mathrm{HT}$ are shown in the insets. Calibration: $0.5 \mathrm{mV}, 5 \mathrm{~ms}$. D, Histograms showing dose-dependent early synaptic depression and late synaptic potentiation. D1, Early synaptic depression induced by different doses of 5-HT measured $30 \mathrm{~min}$ after 5-HT application. D2, L-LTP induced by different doses of 5-HT measured $3.5 \mathrm{~h}$ after 5 -HT application. Error bars indicate the mean \pm SEM.

$106 \pm 12 \%(n=6) ; 3.5 \mathrm{~h}$ after the application of 5-HT; $p<0.01$; Student's $t$ test] (Fig $2 A$ ). In contrast, in the presence of the $5-\mathrm{HT}_{1 \mathrm{~A}}$ receptor antagonist NAN-190 $(20 \mu \mathrm{M})$, the synaptic depression in the first hour was reduced ( $93 \pm 5 \%$ in NAN-190 vs $61 \pm 6 \%$ in control, measured 20 min after 5 -HT; $n=8$ for each group; $p<0.05$ ), but the long-lasting synaptic potentiation (measured $3.5 \mathrm{~h}$ after 5 -HT) was unaffected $(152 \pm 7 \%$ in NAN190 vs $169 \pm 5 \%$ in control; $n=8$ for each group; $p>0.5$ ) (Fig. $2 B)$. These results show clearly that the two components of 5-HT effects are mediated by different 5-HT receptors and that 5-HT-induced L-LTP is mediated primarily by the $5-\mathrm{HT}_{4}$ receptor. We next asked whether L-LTP induced by 5 -HT can be mimicked by the $5-\mathrm{HT}_{4}$ receptor agonist. In the presence of the selective 5-HT reuptake inhibitor zimelidine $(50-100 \mu \mathrm{M})$ application of the partial $5-\mathrm{HT}_{4}$ receptor agonist RS 67333 (50 $\mu \mathrm{M} ; 25 \mathrm{~min}$ ) induced a slowly developed and long-lasting synaptic potentiation in BL [RS 67333 plus zimelidine, $135 \pm 5 \%(n=7)$; vehicle control, $99 \pm$ $6 \%(n=6) ; 3.5 \mathrm{~h} ; p<0.01$ ] (Fig. $2 C)$, whereas zimelidine alone or RS 67333 alone did not elicit LTP (zimelidine alone, $98 \pm 5 \%$; RS 67333 alone, $103 \pm 6 \% ; n=$ 6 for each group; $p>0.5$; ANOVA). Two possible explanations might account for the lack of LTP in slices treated by RS 67333 alone. First, RS 67333 is a partial $5-\mathrm{HT}_{4}$ receptor agonist, so the $5-\mathrm{HT}_{4}$ receptor is not fully activated by RS 67333 (Eglen et al., 1995). Coapplication of a selective 5-HT reuptake inhibitor, which increases the endogenous 5-HT levels (Kim et al., 2002), may produce a synergetic effect with RS 67333 on the activation of the $5-\mathrm{HT}_{4}$ receptor. Alternatively, the activation of the $5-\mathrm{HT}_{4}$ receptor is necessary but may not be sufficient for the induction of LTP. Other 5-HT receptors $\left(5-\mathrm{HT}_{6}\right.$, $\left.5-\mathrm{HT}_{7}\right)$ that also are coupled positively to PKA pathways (Barnes and Sharp, 1999; Bacon and Beck, 2000) may contribute to the 5-HT L-LTP.

\section{5-HT-induced L-LTP in amygdala is mediated by the PKA/MAPK signaling pathway}

The $5-\mathrm{HT}_{4}$ receptor and several other 5-HT receptors $\left(5-\mathrm{HT}_{6}, 5-\mathrm{HT}_{7}\right)$ are coupled positively to the cAMP signaling pathway (Eglen et al., 1995; Barnes and Sharp, 1999). Is the 5-HT-induced synaptic potentiation mediated by PKA? To test this idea, we examined the effect of a PKA inhibitor and found that PKA inhibitor KT5720 (2 $\mu \mathrm{M})$ completely blocked the late and long-lasting synaptic potentiation induced by 5 -HT. At 1 and $3.5 \mathrm{~h}$ after 5 -HT the amplitudes of field potentials were $105 \pm 6$ and $104 \pm 9 \%(n=6)$ of the baseline, significantly different from slices treated with 5-HT alone $(133 \pm 4$ and $167 \pm 7 \% ; n=6 ; p<0.01)$ (Fig. 3A).

Studies in Aplysia indicate that 5-HT recruits MAPK, and the coordinated action of PKA/MAPK is required for the activation of CREB. Inhibition of MAPK blocks 5-HT-induced long-term synaptic facilitation (LTF) in Aplysia (Martin et al., 1997; Michael et al., 1998). Does MAPK play a similar role in L-LTP induced by 5 -HT in neurons of amygdala? We next examined the effect of MAPK inhibitor U0126. As was the case with the inhibitor of 
A

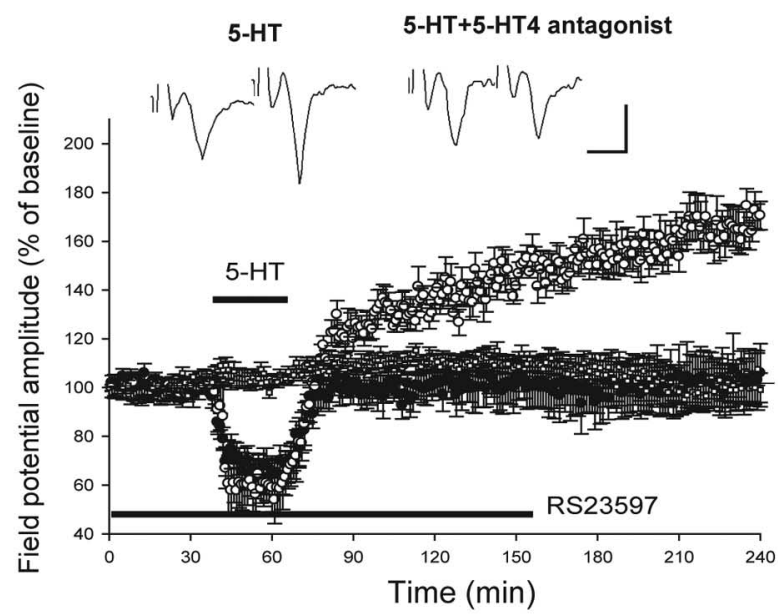

B

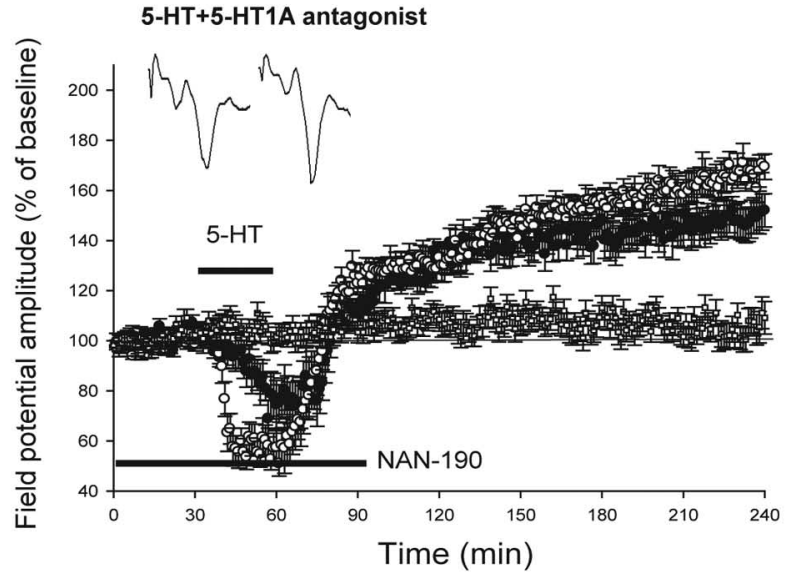

C

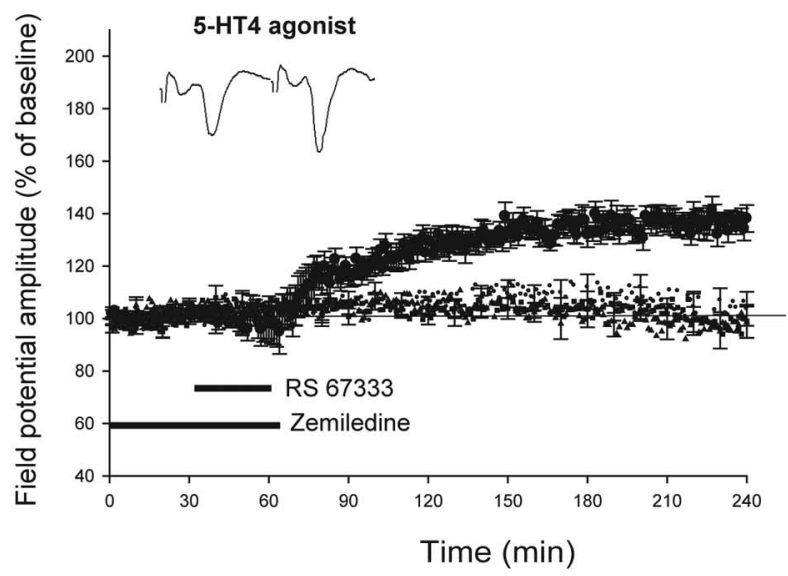

Figure 2. 5 -HT-induced L-LTP in the $\mathrm{BL}$ is mediated by the $5-\mathrm{HT}_{4}$ receptor. $A, 5-\mathrm{HT}_{4}$ receptor antagonist RS 23597 ( $50 \mu \mathrm{m}$; perfused $30 \mathrm{~min}$ before, during $5-\mathrm{HT}$, and 90 min after washout of 5-HT) blocks the L-LTP induced by 5-HT ( $300 \mu \mathrm{M}$ ). 5-HT, Unfilled circles; RS 23597 alone, unfilled squares; RS 23597 plus 5-HT, filled circles. $\boldsymbol{B}, 5-\mathrm{HT}_{1 \mathrm{~A}}$ receptor antagonist NAN-190 (20 $\mu \mathrm{m}$; perfused 60 min before and during 5 -HT application) reduces the early synaptic depression but does not alter the late phase synaptic potentiation. 5-HT, Unfilled circles; NAN-190 alone, unfilled squares; 5-HT plus NAN-190, filled circles. C, 5-HT ${ }_{4}$ receptor agonist RS $67333(50 \mu \mathrm{m})$ induces L-LTP in the BL in the presence of the 5-HT reuptake inhibitor zimelidine. RS 67333 alone, Unfilled circles; zimelidine, filled triangles; RS 67333 plus zimelidine, filled circles; vehicle control, filled squares. Representative field potentials $10 \mathrm{~min}$ before and $3.5 \mathrm{~h}$ after 5 -HT or a 5-HT agonist in each group are shown in the insets. Calibration: $1 \mathrm{mV}, 3 \mathrm{~ms}$. Error bars indicate the mean \pm SEM.
A

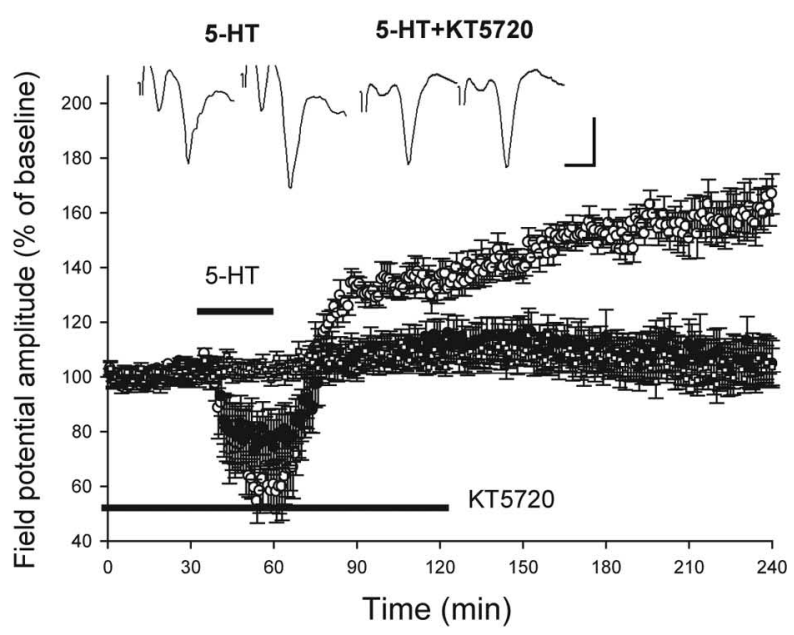

B

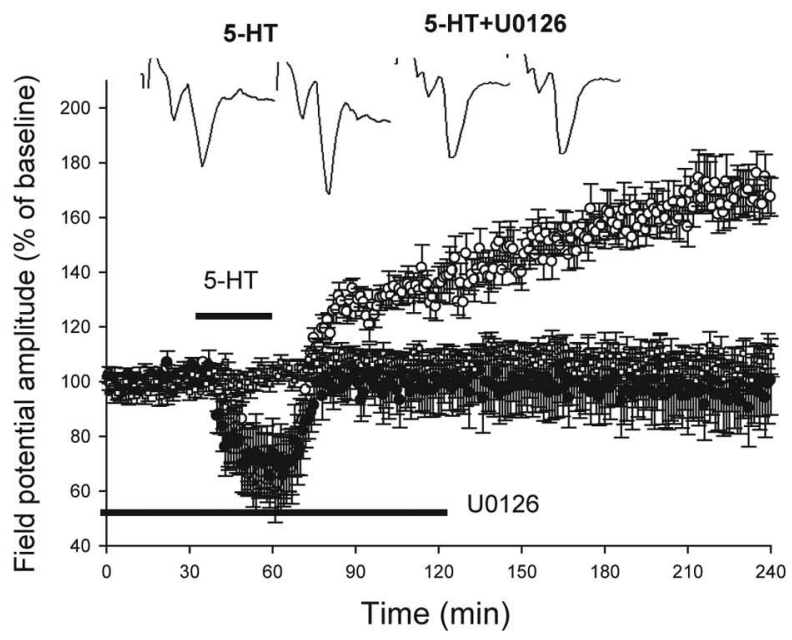

Figure 3. 5-HT-induced L-LTP in the BL depends on the activation of PKA/MAPK. A, PKA inhibitor KT5720 (2 $\mu \mathrm{m})$ blocks L-LTP induced by 5-HT (300 $\mu \mathrm{M})$. 5-HT, Unfilled circles; KT5720 alone, unfilled squares; KT5720 plus 5-HT, filled circles. B, MAPK inhibitor U0126 (10 $\mu \mathrm{m})$ blocks the late synaptic potentiation induced by 5 -HT but does not block the early synaptic depression. 5-HT, Unfilled circles; U0126 alone, unfilled squares; U0126 plus 5-HT, filled circles. Representative field potentials $10 \mathrm{~min}$ before and $3.5 \mathrm{~h}$ after 5 -HT in each group are shown in the insets. Calibration: $1 \mathrm{mV}, 5 \mathrm{~ms}$. Error bars indicate the mean \pm SEM.

PKA, the MAPK inhibitor U0126 (10 $\mu \mathrm{M})$ blocked the late synaptic potentiation induced by 5 -HT [5-HT, $167 \pm 7 \%(n=6)$; 5-HT plus U-0126, $100 \pm 12 \%(n=6) ; 3.5 \mathrm{~h}$ after 5-HT; $p<0.01$; Student's $t$ test] (Fig. $3 B$ ). Although MAPK and PKA inhibitors blocked the L-LTP, they did not block the early synaptic depression induced by $5-\mathrm{HT}$ at this dosage (Fig. $3 A, B$ ). Presumably other signaling pathways, such as calcium/calmodulindependent protein kinase II (CaMKII) and protein kinase C (PKC), may be involved in the mediation of this synaptic depression.

NMDA receptors and L-type voltage-dependent calcium channels (L-VDCCs) play a role in some forms of LTP in amygdala (Huang and Kandel, 1998; Rammes et al., 2000; Blair et al., 2001; Bauer et al., 2002; Maren, 2005). Does LTP induced by 5-HT similarly require the activation of NMDA receptors and L-type calcium channels? As shown in Figure $4 A$, in the presence of NMDA receptor antagonist D-APV $(50 \mu \mathrm{M}) 5-\mathrm{HT}$ still produced an early synaptic depression and L-LTP $(154 \pm 6 \%, n=6$; $3.5 \mathrm{~h}$ after 5-HT), which was not different from that in control 
A

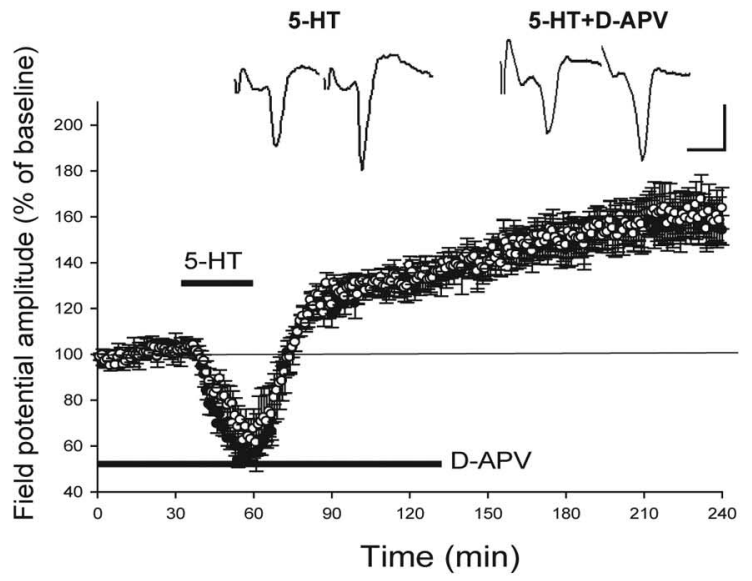

B
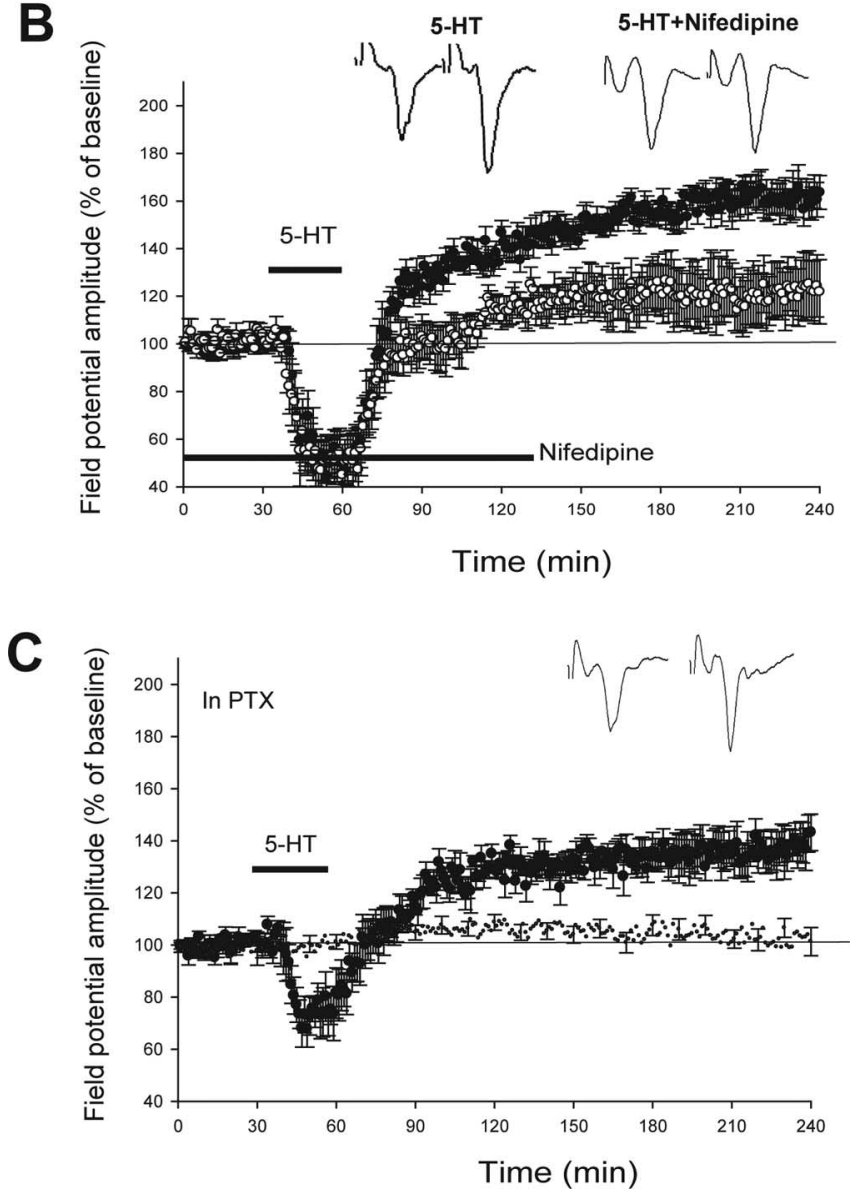

Figure 4. 5-HT-induced L-LTP is independent of NMDA receptors. $A$, In the presence of NMDA receptor antagonist D-APV $(50 \mu \mathrm{M}) 5-\mathrm{HT}(300 \mu \mathrm{m})$ still induces L-LTP, which is not significantly different from that in control experiments. 5 -HT, Unfilled circles; 5 -HT plus D-APV, filled circles. $\boldsymbol{B}$, In the presence of the L-VDCC blocker nifedipine (15 $\mu \mathrm{m})$ L-LTP induced by $5-H T$ was reduced. 5-HT, Unfilled circles; 5-HT plus nifedipine, filled circles. C, 5-HT (300 $\mu \mathrm{M})$ still induces L-LTP in the presence of the GABAergic antagonist picrotoxin. Control, Unfilled circles; 5-HT, filled circles. Representative field potentials $10 \mathrm{~min}$ before and $3.5 \mathrm{~h}$ after 5 - $\mathrm{HT}$ in each group are shown in the insets. Calibration: $1 \mathrm{mV}, 5 \mathrm{~ms}$. Error bars indicate the mean \pm SEM.

experiments ( $158 \pm 10 \% ; n=6 ; p>0.5$; Student's $t$ test) (Fig. $4 A)$. In contrast, L-type calcium channel inhibitor nifedipine (15 $\mu \mathrm{M})$ partially depressed the L-LTP induced by 5 -HT [5-HT, $163 \pm 7 \%(n=6)$; nifedipine plus 5-HT, $122 \pm 12 \%(n=6) ; p<$ 0.05 ; Student's $t$ test; $3.5 \mathrm{~h}$ after $5-\mathrm{HT}$ ], although the early synap- tic depression induced by 5 -HT was not altered (Fig $4 B$ ). These results indicate that 5-HT-induced L-LTP is independent of NMDA receptors but dependent on the activation of L-type calcium channels. 5-HT is known to increase the voltagedependent, nifedipine-sensitive calcium current in Aplysia sensory neurons (Braha et al., 1993). The different blockade effect of L-type calcium channels on 5-HT-induced L-LTP in neurons of amygdala and Aplysia (Edmonds et al., 1990) could be attributable to different sensitivity of the L-type calcium channels to 5 -HT in these two different neurons.

The induction and maintenance of LTP in the LA-BL pathway of mice are facilitated by the blockade of GABAergic inhibition in interneurons (Rammes et al., 2000). 5-HT can activate GABAergic interneurons of the $\mathrm{BL}$ directly via an activation of the $5-\mathrm{HT}_{2}$ receptor (Rainnie, 1999). We therefore examined 5-HT L-LTP in the presence of the GABAergic antagonist picrotoxin $(10 \mu \mathrm{M})$. As shown in Figure 4C, the application of 5-HT still induces a substantial L-LTP in picrotoxin-treated slices [5-HT, $143 \pm 7 \%(n=$ $6)$; control, $101 \pm 5 \%(n=6) ; p<0.01$; Student's $t$ test; $3.5 \mathrm{~h}$ after $5-\mathrm{HT}]$. This result indicates that the $5-\mathrm{HT}_{4}$ receptor-mediated L-LTP in the BL is, at least partly, independent of GABAergic inhibition, which is similar to the synaptic depression mediated by $5-\mathrm{HT}_{1 \mathrm{~A}}$ (Cheng et al., 1998).

\section{5-HT-induced L-LTP in amygdala requires new protein synthesis, gene transcription, and regulation of actin cytoskeleton}

The long-term stabilization of synaptic facilitation induced by 5-HT in Aplysia requires new protein synthesis (Dale et al., 1988). To determine whether such a requirement exits in 5-HT-induced L-LTP in amygdala, we perfused anisomycin, an inhibitor of protein synthesis, into amygdala slices. In the presence of anisomycin $(25 \mu \mathrm{M})$ L-LTP induced by 5 -HT was depressed significantly [5-HT, $163 \pm 9 \%(n=6) ; 5$-HT plus anisomycin, $115 \pm 5 \%(n=$ 6); $3.5 \mathrm{~h}$ after 5-HT; $p<0.01$; Student's $t$ test] (Fig. $5 A$ ).

In Aplysia 5-HT-induced LTF also requires gene transcription (Montarolo et al., 1986). We therefore examined next the effect of transcription inhibitor ACTD. We found that ACTD $(40 \mu \mathrm{M})$ did not block early synaptic depression but blocked completely the L-LTP induced by 5 -HT [5-HT, $173 \pm 9 \%(n=6)$; 5 -HT plus ACTD, $110 \pm 7 \%(n=7) ; 3.5$ h after 5-HT; $p<0.01$; Student's $t$ test] (Fig 5B). As with 5-HT-induced LTF in Aplysia and the L-LTP in hippocampus, the requirement for transcription has a critical time window (Montarolo et al., 1986; Nguyen et al., 1994). When ACTD was applied $2 \mathrm{~h}$ after the application of 5-HT, there was no blockade of 5-HT L-LTP ( 2 h, $148 \pm 8 \%$; 5 h, $150 \pm$ $14 \% ; n=5 ; p>0.5$; Student's $t$ test) (Fig $5 C$ ). These results indicate that new protein synthesis and gene transcription, mediated by the PKA/MAPK signaling pathway, are required for the maintenance of 5-HT-induced L-LTP in the amygdala.

The protein synthesis-dependent long-term synaptic potentiation in both Aplysia and hippocampus are associated with structural changes. One of the critical steps involved in synaptic remodeling is thought to be the reorganization of actin cytoskeleton. Actin polymerization inhibitors block 5-HTinduced LTF and the LTF-associated morphological changes in the sensory neurons of Aplysia (Hatada et al., 2000; Udo et al., 2005) and selectively block L-LTP in hippocampus (Krucker et al., 2000; Fukazawa et al., 2003; Huang and Kandel, 2005). Does L-LTP induced by 5-HT in neurons of the BL depend on the regulation of actin cytoskeleton? We examined the effect of cytochalasin $\mathrm{D}$, an inhibitor of actin polymerization. In the presence of cytochalasin D (10 $\mu \mathrm{M})$ 5-HT still induced an early syn- 
aptic depression; however, the late facilitation was blocked completely [5-HT, $162 \pm 8 \%(n=6)$; 5-HT plus cytochalasin D, $98 \pm 3 \%(n=7) ; p<0.01$; Student's $t$ test; $3.5 \mathrm{~h}$ after 5-HT] (Fig 5D). As a control, when cytochalasin D $(10 \mu \mathrm{M})$ was applied $2 \mathrm{~h}$ after 5 -HT, L-LTP was not affected $(2 \mathrm{~h}, 150 \pm 8 \% ; 5 \mathrm{~h}, 165 \pm 12 \%$; $n=6 ; p>0.5$; Student's $t$ test) (Fig. $5 E$ ). These results indicate that activation of the 5-HT receptor may stimulate rearrangements of cytoskeletal protein and that 5-HT-induced L-LTP may accompanied by synaptic remodeling of neurons in amygdala.

\section{5-HT-induced LTP occludes LTP induced by electrical tetanization} Repeated tetanization induces LTP in the LA and BL of amygdala in mice (Rammes et al., 2000; Huang et al., 2005). We next asked about the relationship between 5-HT-induced LTP and the LTP induced by electrical tetanization in the $\mathrm{BL}$ of amygdala. At $3 \mathrm{~h}$ after 5-HT-induced LTP we applied eight tetanus trains $(4 \times 2$ trains; $100 \mathrm{~Hz}$; $1 \mathrm{~s}$, in 3 min intervals) to the same synaptic pathway. The tetanization applied in 5-HT-treated slices induced only a transient synaptic potentiation, and the synaptic transmission after high-frequency stimulation (HFS) gradually dropped to $\sim 75 \%$ of the pre-tetanus level. In contrast, $4 \times 2$ tetanus trains ( 100 $\mathrm{Hz} ; 1 \mathrm{~s}$ ) induced a moderate LTP in control slices [control, $136 \pm 8 \%(n=5)$; 5-HT-treated slices, $86 \pm 10 \%(n=6)$; measured 30 min after tetanus; $p<0.01$; Student's $t$ test] (Fig. 6). The occlusion of HFS LTP in 5-HT-treated slices may be caused by both 5-HT and HFS activating the PKA signaling pathway. Indeed, we found that L-LTP induced by HFS also was blocked by the $5-\mathrm{HT}_{4}$ receptor antagonist [control, $145 \pm 8 \%(n=6)$; RS 23597, $110 \pm 4 \%(n=5)$; measured $3.5 \mathrm{~h}$ after HFS; $p<0.01$; Student's $t$ test] (Fig 6B); PKA activation and new protein synthesis were required for the maintenance of L-LTP induced by HFS [control, $149 \pm 3 \%(n=6)$; KT5720, $120 \pm 3 \%(n=5)$; anisomycin, $118 \pm$ $2 \%(n=5)$; measured $3.5 \mathrm{~h}$ after HFS; $p<0.01$; ANOVA] (Fig 6C).

\section{Discussion}

Dual effects of 5-HT on synaptic plasticity in amygdala We here demonstrate that 5-HT has dual plastic effects on synaptic transmission in the amygdala. In addition to the early transient synaptic depression mediated by $5-\mathrm{HT}_{1 \mathrm{~A}}$ (Cheng et al., 1998; Wang et al., 1999), 5-HT also induces a late synaptic facilitation that lasts $>5 \mathrm{~h}$. This late and long-lasting synaptic facili-
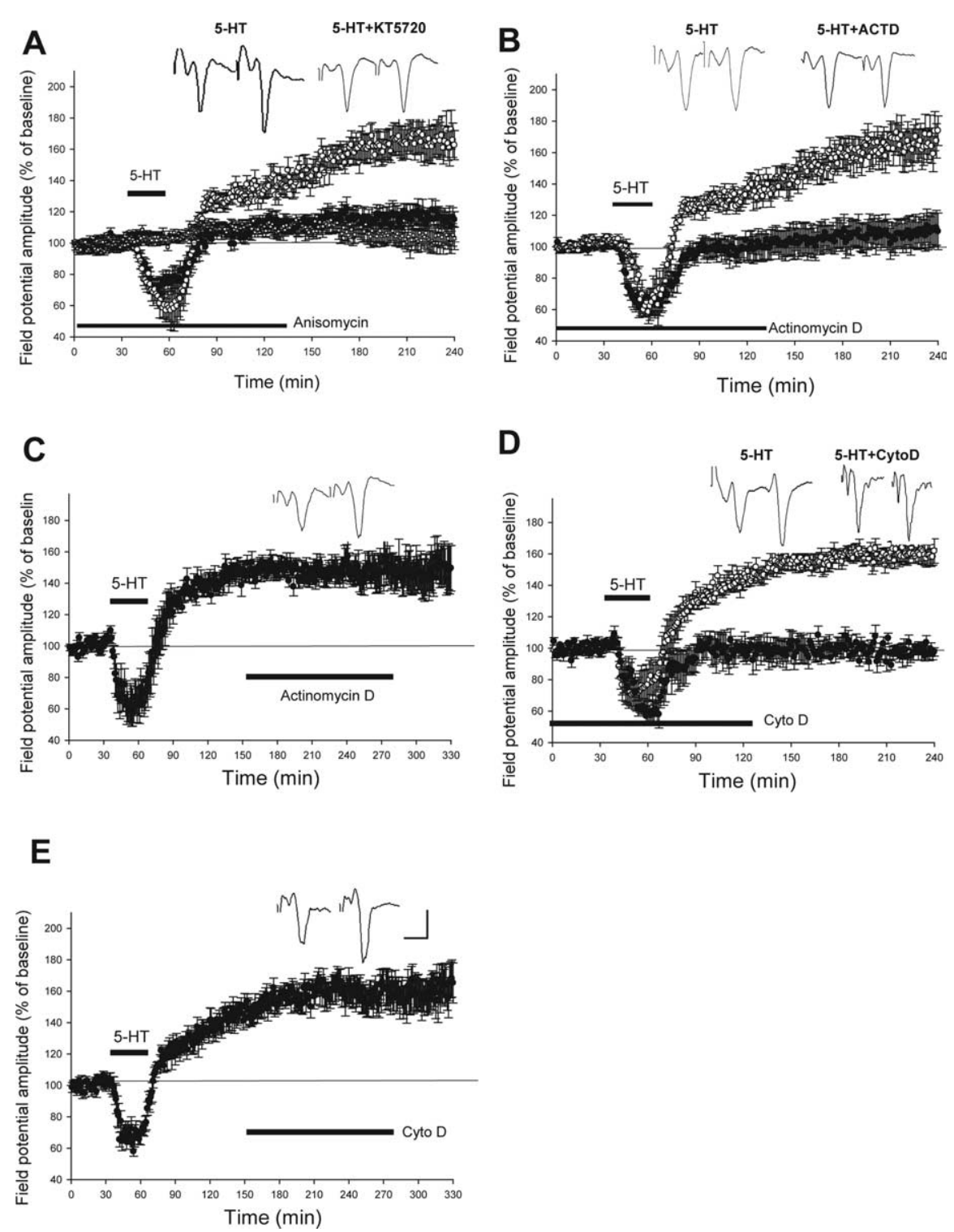

Figure 5. Gene transcription and actin cytoskeletal regulation are required for 5-HT L-LTP. A, Protein synthesis inhibitor anisomycin ( $25 \mu \mathrm{m}$; applied $60 \mathrm{~min}$ before, during, and $60 \mathrm{~min}$ after washout of 5-HT) blocks the late synaptic potentiation induced by 5-HT. 5-HT, Unfilled circles; anisomycin alone, unfilled squares; anisomycin plus 5-HT, filled circles. Insets show the representative field potentials $10 \mathrm{~min}$ before and $3.5 \mathrm{~h}$ after $5-\mathrm{HT}$ in each group. Calibration: $1 \mathrm{mV}, 3 \mathrm{~ms}$. B, Transcription inhibitor ACTD ( $40 \mu$ m; perfused 30 min before, during, and 60 min after washout of 5 -HT) does not affect the synaptic depression but blocks the L-LTP induced by 5-HT $(300 \mu \mathrm{M})$. 5-HT, Unfilled circles; 5 -HT plus ACTD, filled circles. Insets show the representative field potentials $10 \mathrm{~min}$ before and $3.5 \mathrm{~h}$ after 5 -HT in each group. C, ACTD applied $2 \mathrm{~h}$ after the application of 5 -HT does not alter the L-LTP induced by 5 -HT. Insets show the representative field potentials $10 \mathrm{~min}$ before (left) and $5 \mathrm{~h}$ after (right) 5 -HT. D, Actin polymerization inhibitor cytochalasin D (Cyto D; $10 \mu \mathrm{m}$; perfused into slices $60 \mathrm{~min}$ before, during, and 90 min after washout of 5-HT) blocks the L-LTP induced by 5-HT ( $300 \mu \mathrm{M}) .5$-HT, Unfilled circles; 5 -HT plus (yto D, filled circles. Insets show representative

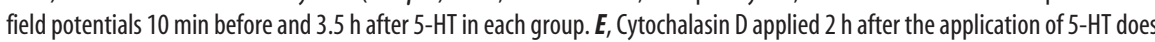
not alter the L-LTP induced by 5-HT. Insets show representative field potentials $10 \mathrm{~min}$ before (left) and $5 \mathrm{~h}$ after (right) 5 -HT. Calibration: $1 \mathrm{mV}, 5 \mathrm{~ms}$. Error bars indicate the mean \pm SEM.

tation is mediated primarily by the $5-\mathrm{HT}_{4}$ receptor and requires $\mathrm{PKA} / \mathrm{MAPK}$, new protein synthesis, and gene transcription.

5-HT receptors are divided into seven subtypes: 5- $\mathrm{HT}_{1}-5$ $\mathrm{HT}_{7}$. Among these subtypes $5-\mathrm{HT}_{4}$ and $5-\mathrm{HT}_{1 \mathrm{~A}}$ are two subtypes of 5-HT receptor that are coupled with cAMP via G-protein in opposite directions. The $5-\mathrm{HT}_{1 \mathrm{~A}}$ receptor is coupled negatively to the cAMP signaling pathway (Barnes and Sharp, 1999). In contrast, the $5-\mathrm{HT}_{4}$ receptor is coupled positively to cAMP (Eglen et al., 1995; Torres et al., 1996; Barnes and Sharp, 1999; Heine et al., 2002). In striatal slices the application of 5-HT (100 $\mu \mathrm{M})$ causes 


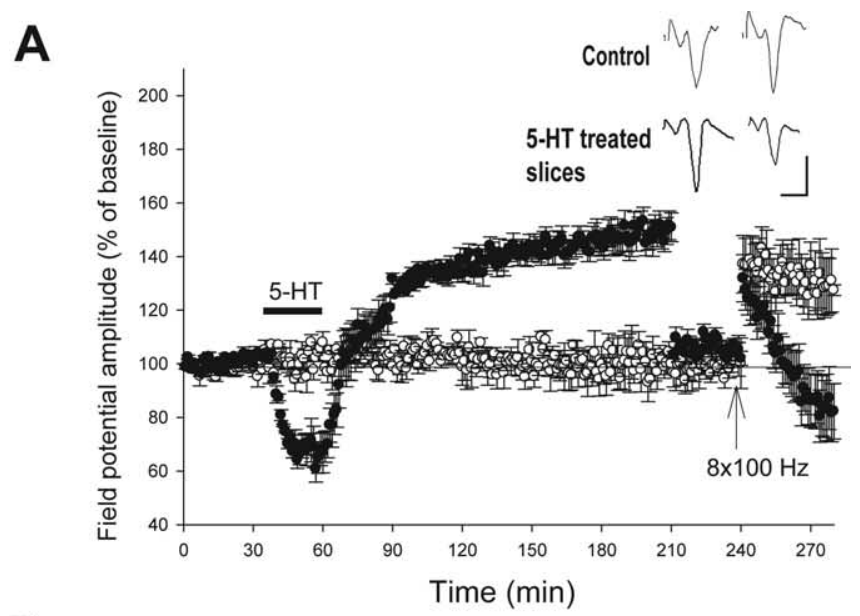

B
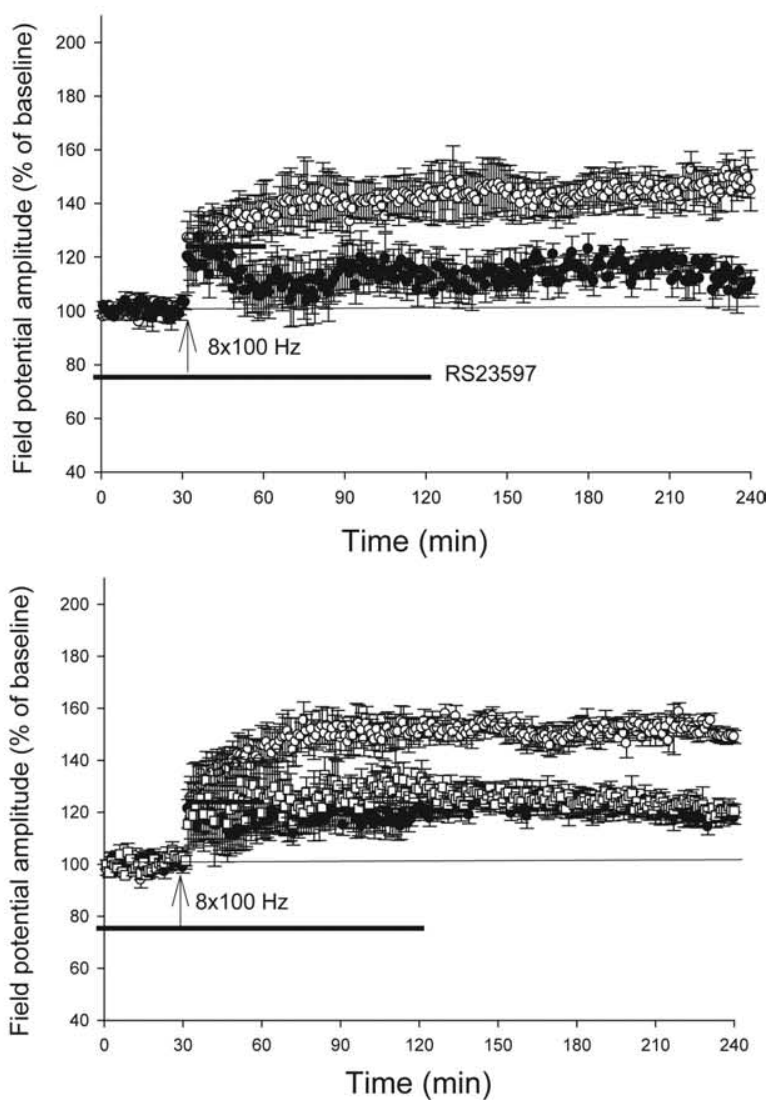

Figure 6. 5-HT-induced L-LTP occludes the LTP induced by electrical tetanus. $\boldsymbol{A}, 5-\mathrm{HT}$ L-LTP occludes subsequent L-LTP induced by HFS. At $3 \mathrm{~h}$ after the application of 5-HT (300 $\mu \mathrm{m})$ the stimulus intensity was reduced to match the amplitude of baseline potential before 5 - $\mathrm{HT}$, and eight trains of tetanus ( $4 \times 2$ trains of $100 \mathrm{~Hz}$ of stimulation in 3 min intervals) were applied. These tetanus trains failed to induce LTP in 5-HT-treated slices. LTP induced by eight trains of tetanus in control experiments, Unfilled circles; LTP in 5-HT-treated slices, filled circles. Insets, Representative field potentials before (left) and $40 \mathrm{~min}$ after (right) tetanus in control and in 5-HT-treated slices. Calibration: $1 \mathrm{mV}, 5 \mathrm{~ms}$. B, 5- $\mathrm{HT}_{4}$ receptor antagonist RS 23597 (50 $\mu \mathrm{m}$ ) blocks the L-LTP induced by HFS ( $4 \times 2$ trains of $100 \mathrm{~Hz}$ ). Control, Unfilled circles; RS 23597, filled circles. C, PKA inhibitor KT5720 (2 $\mu \mathrm{m})$ and protein synthesis inhibitor anisomycin ( $25 \mu \mathrm{M})$ block L-LTP induced by HFS. Control, Unfilled circles; KT5720, unfilled squares; anisomycin, filled circles. Error bars indicate the mean \pm SEM.

an increased phosphorylation of the PKA sites of Thr34/ DARPP-32 (threonine 34/dopamine and cAMP-regulated phosphoprotein). This effect could be blocked by the $5-\mathrm{HT}_{4}$ antagonist and PKA inhibitor recombinant protein-cAMP (Sven- ningsson et al., 2002). Activation of the 5- $\mathrm{HT}_{4}$ receptor increases neuronal excitability in hippocampal neurons (Andrade and Chaput, 1991; Ansanay et al., 1995; Torres et al., 1996; Chapin et al., 2002; Spencer et al., 2004; Kemp and Vaughan, 2005) and in prefrontal cortex (Beique et al., 2004). 5- $\mathrm{HT}_{4}$ receptor agonists enhance the magnitude of population spikes recorded in the CA1 region of hippocampus (Siarey et al., 1995; Spencer et al., 2004). In neurons of colliculus and hippocampus the activation of the $5-\mathrm{HT}_{4}$ receptor can inhibit $\mathrm{K}^{+}$current and reduce afterhyperpolarization, which increases neuronal excitability and neurotransmitter release. These effects occur via the mediation of cAMP/ PKA (Ansanay et al., 1995; Eglen et al., 1995; Heine et al., 2002)

The $\mathrm{BL}$ of amygdala is rich in $5-\mathrm{HT}_{4}$ receptors (Waeber et al., 1993, 1994, 1996; Jakeman et al., 1994; Eglen et al., 1995; Vilaro et al., 2005). Although there are reports that the activation of the $5-\mathrm{HT}_{4}$ receptor plays facilitative roles in neurons of the hippocampus, the role of the $5-\mathrm{HT}_{4}$ receptor on the synaptic transmission in amygdala synapse is not known. Indeed, most of previous studies in the BL of amygdala limited the recording to $\sim 1 \mathrm{~h}$, and thus the slowly developing and long-lasting effect of 5-HT was not observed. Our results demonstrate that, in addition to the early depression effect mediated by $5-\mathrm{HT}_{1 \mathrm{~A}}, 5-\mathrm{HT}$ also produces the $5-\mathrm{HT}_{4}$ receptor/PKA-dependent late facilitation of synaptic transmission in neurons of amygdala. In contrast to early synaptic depression, the $5-\mathrm{HT}_{4}$ receptor-mediated late synaptic facilitation requires new protein synthesis, gene transcription, and cytoskeletal rearrangement. This long-term effect of 5-HT may be very important to the long-term storage of amygdala-based emotional behavior, which also requires new protein synthesis. The long-lasting synaptic potentiation induced by 5 -HT also may be involved in the long-term effect of 5-HT-based antidepressant drugs.

The depressive effect of $5-\mathrm{HT}_{1 \mathrm{~A}}$ receptor activation and the facilitative effect $5-\mathrm{HT}_{4}$ receptor activation on synaptic plasticity are also consistent with the opposite effects of 5- $\mathrm{HT}_{1 \mathrm{~A}}$ and $5-\mathrm{HT}_{4}$ receptors in behavioral studies. In general, activation of the $5-\mathrm{HT}_{4}$ receptor facilitates memory, and activation of the 5- $\mathrm{HT}_{1 \mathrm{~A}}$ receptor impairs memory. For instance, administration of $5-\mathrm{HT}_{4}$ receptor agonists enhances acquisition and performance of spatial learning (Fontana et al., 1997; Terry et al., 1998; Lamirault and Simon, 2001; Lelong et al., 2001). The 5- $\mathrm{HT}_{4}$ antagonist impairs olfactory-associated memory (Marchetti et al., 2000). In $5-\mathrm{HT}_{4}$ receptor knock-out mice the responses to stress and novelty are attenuated (Compan et al., 2004). In contrast, injection of the $5-\mathrm{HT}_{1 \mathrm{~A}}$ agonist impairs retention, and administration of the $5-\mathrm{HT}_{1 \mathrm{~A}}$ antagonist enhances the retention of passive-avoidance task (Liang, 1999; Schneider et al., 2003). In 5-HT 1A $_{\text {knock-out }}$ mice the fear response to contextual clues increases (Toth, 2003; Klemenhagen et al., 2006).

\section{Learned fear memory in invertebrates and vertebrates may share some common synaptic mechanism}

Learned fear is a form of implicit memory. The synaptic mechanism for learned fear in invertebrates such as Aplysia and Drosophila has been well studied. In Aplysia neurons 5-HT inhibits $\mathrm{K}^{+}$current through cAMP/PKA, leading to spike broadening and prolonged enhancement of transmitter release from the sensory neuron to the motor neuron (LTF). LTF is thought to underlie the enhancement of the gill withdrawal reflex of Aplysia in response to aversive stimulation (Kandel, 2001). In contrast, much less is known about the signaling pathway underlying the long-term storage of learned fear in mammals. The amygdala is an important locus for defensive memory in mammals. More- 
over, the synaptic circuitry for learned fear in the amygdala is relative simple, and the correlation between synaptic strength and behavior is possibly clearer than for hippocampus and spatial memory. Previous studies has revealed that long-term synaptic facilitation in the cortical-amygdala synaptic pathway requires the activation of PKA-mediated protein synthesis, similar to LTF in Aplysia (Huang and Kandel, 1998; Huang et al., 2000, 2005). The present finding of involvement of 5-HT in the protein synthesis and gene expression-dependent long-term synaptic facilitation in amygdala provides additional evidence for the similar signaling pathway for the memory-related changes of synaptic plasticity between Aplysia and mammals. It appears that LTF (L-LTP) in both Aplysia and the mammalian amygdala requires 5-HT-mediated activation of the PKA/MAPK cascade, which subsequently leads to the synthesis of new protein and CREBmediated gene expression, Moreover, both 5-HT-induced LTF in Aplysia and L-LTP in amygdala are associated with actin cytoskeletal-regulated morphological changes. Although the mechanisms of plasticity at different synapses are unlikely to be identical, additional studies of 5-HT in the synaptic plasticity of amygdala and fear memory, using approaches similar to those used in studies of Aplysia, are likely to provide additional insights into the conserved common synaptic mechanism underlying memory storage for learned fear across the simple models in invertebrate and mammals.

\section{References}

Amorapanth P, LeDoux JE, Nader K (2000) Different lateral amygdala outputs mediate reactions and actions elicited by a fear-arousing stimulus. Nat Neurosci 3:74-79.

Andrade R, Chaput Y (1991) 5-Hydroxytryptamine 4-like receptors mediate the slow excitatory response to serotonin in the rat hippocampus. J Pharmacol Exp Ther 257:930-937.

Anglada-Figueroa D, Quirk GJ (2005) Lesions of basal amygdala block expression of conditioned fear but not extinction. J Neurosci 25:9680-9685.

Ansanay H, Dumuis A, Sebben M, Bockaert J, Fagni L (1995) cAMPdependent, long-lasting inhibition of a $\mathrm{K}^{+}$current in mammalian neurons. Proc Natl Acad Sci USA 92:6635-6639.

Azmitia EC, Gannon PJ (1986) The primate serotonergic system: a review of human and animal studies and a report on Macaca fascicularis. Adv Neurol 43:407-468.

Azmitia EC, Segal M (1978) An autoradiographic analysis of the differential ascending projections of the dorsal and median raphe nuclei in the rat. J Comp Neurol 179:641-668.

Bacon WL, Beck SG (2000) 5-Hydroxytrypatamine 7 receptor activation decreases slow afterhyperpolarization amplitude in CA3 hippocampal pyramidal cells. J Pharmacol Exp Ther 294:672-679.

Barnes NM, Sharp T (1999) A review of central 5-HT receptors and their function. Neuropharmacology 38:1083-1152.

Bauer EP, Schafe GE, LeDoux JE (2002) NMDA receptors and L-type voltage-gated calcium channels contribute to long-term potentiation and different components of fear memory formation in the lateral amygdala. J Neurosci 22:5239-5249.

Beique J-C, Chapin-Penick EM, Mladenovic L, Andrade R (2004) Serotonergic facilitation of synaptic activity in the developing rat prefrontal cortex. J Physiol (Lond) 556:739-754.

Blair HT, Schafe GE, Bauer E, Rodrigues SM, LeDoux JE (2001) Synaptic plasticity in the lateral amygdala: a cellular hypothesis of fear conditioning. Learn Mem 8:229-242.

Braha O, Edmonds B, Sactor T, Kandel ER, Klein M (1993) The contributions of protein kinase $\mathrm{A}$ and protein kinase $\mathrm{C}$ to the actions of 5-HT on the L-type $\mathrm{Ca}^{2+}$ current of the sensory neurons in Aplysia. J Neurosci 13:1839-1851.

Chapin EM, Haj-Dahmane S, Torres G, Andrade R (2002) 5- $\mathrm{HT}_{4}$ receptorinduced depolarization in rat hippocampal neurons is mediated by cAMP but is independent of $I_{\mathrm{h}}$. Neurosci Lett 324:1-4.

Cheng L-L, Wang S-J, Gean PW (1998) Serotonin depresses excitatory synaptic transmission and depolarization-evoked $\mathrm{Ca}^{2+}$ influx in rat basolateral amygdala via 5-HT1A receptors. Eur J Neurosci 10:2163-2172.
Compan V, Zhuo M, Grailhe R, Gazzara RA, Martin R, Gingrich J, Dumuis A, Brunner D, Bockaert J, Hen R (2004) Attenuated response to stress and novelty and hypersensitivity to seizures in $5-\mathrm{HT}_{4}$ receptor knock-out mice. J Neurosci 24:412-419.

Corcoran KA, Quirk GJ (2007) Activity in prelimbic cortex is necessary for the expression of learned, but not innate, fears. J Neurosci 27:840-844.

Dale N, Schacher S, Kandel ER (1988) Long-term facilitation in Aplysia involves increase in transmitter release. Science 239:282-285.

DeBock F, Kurz J, Azad SC, Parsons CG, Hapfelmeier G, Zieglgansberger W, Rammes G (2003) $\alpha_{2}$-Adrenoreceptor activation inhibits LTP and LTD in the basolateral amygdala: involvement of $\mathrm{G}_{\mathrm{i} / \mathrm{o}}$-protein-mediated modulation of $\mathrm{Ca}^{2+}$ channels and inwardly rectifying $\mathrm{K}^{+}$channels in LTD. Eur J Neurosci 17:1411-1424.

Edmonds B, Klein M, Dale N, Kandel ER (1990) Contributions of two types of calcium channels to synaptic transmission and plasticity. Science 250:1142-1147.

Eglen RM, Wong HF, Dumuis A, Bockaert J (1995) Central 5-HT4 receptors. Trends Pharmacol Sci 16:391-398.

Fontana DJ, Daniels SE, Wong EH, Clark RD, Eglen RM (1997) The effects of novel, selective 5-hydroxytryptamine (5-HT) 4 receptor ligands in rat spatial navigation. Neuropharmacology 36:689-696.

Fukazawa Y, Saitoh Y, Ozawa F, Ohta Y, Mizuno K, Inokuchi K (2003) Hippocampal LTP is accompanied by enhanced F-actin content within the dendritic spine that is essential for late LTP maintenance in vivo. Neuron 38:447-460.

Gale GD, Anagnostaras SG, Godsil BP, Michell S, Nozawa T, Sage JR, Wiltgen B, Fanselow MS (2004) Role of the basolateral amygdala in the storage of fear memories across the adult lifetime of rats. J Neurosci 24:3810-3815.

Gordon JA, Hen R (2004) The serotonergic system and anxiety. Neuromolecular Med 5:27-40.

Graeff FG, Viana MB, Mora PO (1997) Dual role of 5-HT in defense and anxiety. Neurosci Biobehav Rev 6:791-799.

Griebel G (1995) 5-Hydroxytryptamine-interacting drugs in animal models of anxiety disorders: more than 30 years of research. Pharmacol Ther 65:319-395.

Hariri AR, Mattay VS, Tessitore A, Kolachana B, Fera F, Goldman D, Egan MF, Weinberger DR (2002) Serotonin transporter genetic variation and the response of the human amygdala. Science 297:400-403.

Hatada Y, Wu F, Sun Z-Y, Schacher S, Goldberg DJ (2000) Presynaptic morphological changes associated with long-term synaptic facilitation are triggered by actin polymerization at preexisting varicosities. J Neurosci 20:RC82(1-5).

Heine M, Ponimaskin E, Bickmeyer UIF, Richter DW (2002) 5-HTreceptor-induced changes of the intracellular cAMP level monitored by a hyperpolarization-activated cation channel. Eur J Physiol 443:418-426.

Huang Y-Y, Kandel ER (1998) Postsynaptic induction and PKA-dependent expression of LTP in the lateral amygdala. Neuron 21:169-178.

Huang Y-Y, Kandel ER (2005) Theta frequency stimulation induces a local form of late-phase LTP in CA1 region of hippocampus. Learn Mem 12:587-593.

Huang Y-Y, Martin KC, Kandel ER (2000) Both protein kinase A and mitogen-activated protein kinase are required in the amygdala for the micromolecular synthesis-dependent late phase of long-term potentiation. J Neurosci 20:6317-6325.

Huang Y-Y, Zacharenko SS, Schoch S, Kaeser PS, Janz R, Sudhof TC, Siegelbaum SA, Kandel ER (2005) Genetic evidence for a protein kinase A-mediated presynaptic component in NMDA receptor-dependent forms of long-term synaptic potentiation. Proc Natl Acad Sci USA 102:9365-9370.

Jakeman LB, To ZP, Eglen RM, Wong EH, Bonhaus DW (1994) Quantitative autoradiography of $5-\mathrm{HT}_{4}$ receptors in brains of three species using two structurally distinct radioligands, $\left[{ }^{3} \mathrm{H}\right]$ GR13808 and $\left[{ }^{3} \mathrm{H}\right]$ BIMU- 1 . Neuropharmacology 33:1027-1038.

Kandel ER (2001) The molecular biology of memory storage: a dialogue between genes and synapses. Science 294:1030-1038.

Kawahara H, Yoshida M, Yokoo H, Nishi M, Tanaka M (1993) Psychological stress increases serotonin release in the rat amygdala and prefrontal cortex assessed by in vivo microdialysis. Neurosci Lett 162:81-84.

Keele NB (2005) The role of serotonin in impulsive and aggressive behaviors associated with epilepsy-like neuronal hyperexcitability in the amygdala. Epilepsy Behav 7:325-335.

Kemp A, Vaughan DM (2005) The 5-hydroxytryptamine 4 receptor exhib- 
its frequency-dependent properties in synaptic plasticity and behavioral metaplasticity in the hippocampal CA1 region in vivo. Cereb Cortex 15:1037-1043.

Kim SW, Park SY, Hwang O (2002) Up-regulation of tryptophan hydroxylase expression and serotonin synthesis by sertraline. Mol Pharmacol 61:778-785.

Klemenhagen KC, Gordon JA, David DJ, Hen R, Gross CT (2006) Increased fear response to contextual cues in mice lacking the 5-HT1A receptor. Neuropsychopharmacology 31:1-11.

Krucker T, Siggins GR, Halpain S (2000) Dynamic actin filaments are required for stable long-term potentiation (LTP) in area CA1 of the hippocampus. Proc Natl Acad Sci USA 97:6856-6861.

Lamirault L, Simon H (2001) Enhancement of place and object recognition memory in young adult and old rat by RS 67333, a partial agonist of 5-HT4 receptors. Neuropharmacology 41:844-853.

LeDoux JE (2000) Emotion circuits in the brain. Annu Rev Neurosci 23:155-184.

Lelong V, Dauphin F, Boulouard M (2001) RS 67333 and D-cycloserine accelerate learning acquisition in the rat. Neuropharmacology 41:517-522.

Liang KC (1999) Pre- or post-training injection of buspirone impaired retention in the inhibitory avoidance task: involvement of amygdala 5-HT1A receptors. Eur J Neurosci 11:1491-1500.

Lin HC, Wang S-J, Luo M-Z, Gean P-W (2000) Activation of group II metabotropic glutamate receptors induces long-term depression of synaptic transmission in the rat amygdala. J Neurosci 20:9017-9024.

Lucki I (1998) The spectrum of behaviors influenced by serotonin. Biol Psychiatry 44:151-162.

Ma QP, Yin GF, Ai MK, Han JS (1991) Serotonin projections from the nucleus raphe dorsalis to amygdala in the rat. Neurosci Lett 134:21-24.

Macedo CE, Cuadra G, Molina V, Brandao L (2004) Aversive stimulation of the inferior colliculus changes dopamine and serotonin extracellular levels in the frontal cortex: modulation by the basolateral nucleus of amygdala. Synapse 55:58-66.

Macedo CE, Martinez CR, Souza de Silva MA, Brandao ML (2005) Increase in extracellular levels of 5-HT and dopamine in the basolateral, but not in the central nucleus, of amygdala induced by aversive stimulation of the inferior colliculus. Eur J Neurosci 21:1131-1138.

Marchetti E, Dumuis A, Bockaert J, Soumireu-Mourat B, Roman FS (2000) Differential modulation of the 5-HT4 receptor agonists and antagonist on rat learning and memory. Neuropharmacology 39:2017-2027.

Maren S (2003) The amygdala, synaptic plasticity, and fear memory. Ann NY Acad Sci 985:106-113.

Maren S (2005) Synaptic mechanisms of associative memory in the amygdala. Neuron 47:783-786.

Martin K, Michael D, Rose JC, Barad M, Casadio A, Zhu H, Kandel ER (1997) MAP kinase translocates into the nucleus of the presynaptic cell and is required for long-term facilitation in Aplysia. Neuron 18:899-912.

McGregor IS, Clemens KJ, Van der Plasse G, Li KM, Hunt GE, Chen F, Lawrence AJ (2003) Increased anxiety 3 months after brief exposure to MDMA ("Ecstasy") in rats: association with altered 5-HT transporter and receptor density. Neuropsychopharmacology 28:1472-1484.

McKernan MG, Shinnick-Gallagher P (1997) Fear conditioning induces a lasting potentiation of synaptic currents in vitro. Nature 390:607-611.

Michael D, Martin KC, Seger R, Ning M-M, Baston R, Kandel ER (1998) Repeated pulses of serotonin required for long-term facilitation activate mitogen-activated protein kinase in sensory neurons of Aplysia. Proc Natl Acad Sci USA 95:1864-1869.

Montarolo PG, Goelet P, Castellucci VF, Morgan J, Kandel ER, Schacher S (1986) A critical period for macromolecular synthesis in long-term heterosynaptic facilitation in Aplysia. Science 234:1249-1254.

Nguyen PV, Abel T, Kandel ER (1994) Temporal and spatial regulation of transcription for induction of a late phase of LTP. Science 265:1104-1107.

Rainnie DG (1999) Serotonergic modulation of neuron transmission in the rat basolateral amygdala. J Neurophysiol 82:69-85.

Rammes G, Steckler T, Kresse A, Schutz G, Zieglgansberger W, Lutz B (2000) Synaptic plasticity in the basolateral amygdala in transgenic mice expressing dominant-negative cAMP response element-binding protein (CREB) in forebrain. Eur J Neurosci 12:2534-2546.
Rogan MT, Staubli UV, LeDoux JE (1997) Fear conditioning induces associative long-term potentiation in the amygdala. Nature 390:604-607.

Rogan MT, Leon KS, Perez DL, Kandel ER (2005) Distinct neural signatures for safety and danger in the amygdala and striatum of the mouse. Neuron 46:309-320.

Schafe GE, Nader K, Blair HT, LeDoux JE (2001) Memory consolidation of pavlovian fear conditioning: a cellular and molecular perspective. Trends Neurosci 24:540-546.

Schneider AM, Wilkins E, Firestone A, Everbach EC, Naylor JC, Simson PE (2003) Enhanced retention in the passive-avoidance task by $5-\mathrm{HT}_{1 \mathrm{~A}}$ receptor blockade is not associated with increased activity of the central nucleus of the amygdala. Learn Mem 10:394-400.

Schroeder BW, Shinnick-Gallagher P (2004) Fear memories induce a switch in stimulus response and signaling mechanisms for long-term potentiation in the lateral amygdala. Eur J Neurosci 20:549-556.

Schroeder BW, Shinnick-Gallagher P (2005) Fear learning induces persistent facilitation of amygdala synaptic transmission. Eur J Neurosci 22:1775-1783.

Siarey RJ, Andreasen M, Lambert JD (1995) Serotoninergic modulation of excitability in area CA1 of the in vitro rat hippocampus. Neurosci Lett 199:211-214.

Spencer JP, Brown JT, Richardson JC, Medhurst AD, Sehmi SS, Calver AR, Randall AD (2004) Modulation of hippocampal excitability by 5-HT4 receptor agonist persists in a transgenic model of Alzheimer's disease. Neuroscience 129:49-54.

Stefanacci L, Farb CR, Pitkanen A, Go G, LeDoux JE, Amaral DG (1992) Projections from the lateral nucleus to the basal nucleus of amygdala: a light and electron microscopic PHA-L study in the rat. J Comp Neurosci 15:8259-8301.

Svenningsson P, Tzavara ET, Liu F, Fienberg AA, Nomikos GG, Greengard P (2002) DARPP-32 mediates serotonergic neurotransmission in the forebrain. Proc Natl Acad Sci USA 99:3188-3193.

Terry Jr AV, Buccafusco JL, Jackson WJ, Prendergast MA, Fontana DJ, Wong EH, Bonhaus DW, Weller P, Eglen RM (1998) Enhanced delayed matching performance in younger and older macaques administered the 5-HT4 receptor agonist, RS17017. Psychopharmacology 135:407-415.

Torres GE, Arfken CL, Andrade R (1996) 5-Hydroxytryptamine 4 receptors reduce afterhyperpolarization in hippocampus by inhibiting calciuminduced calcium release. Mol Pharmacol 50:1316-1322.

Toth M (2003) 5-HT1A knockout mouse as a genetic model of anxiety. Eur J Pharmacol 463:177-184.

Tsvetkov E, Carlezon WA, Benes FM, Kandel ER, Bolshakov V (2002) Fear conditioning occludes LTP-induced presynaptic enhancement of synaptic transmission in the cortical pathway to the lateral amygdala. Neuron 34:289-300.

Udo H, Jin I, Kim J-H, Li H-L, Youn T, Hawkins RD, Kandel ER, Bailey CH (2005) Serotonin-induced regulation of actin network for learningrelated synaptic growth requires Cdc42, N-WASP, and PKA in Aplysia sensory neurons. Neuron 45:887-901.

Vilaro MT, Cortes R, Mengod G (2005) Serotonin 5-HT4 receptors and their mRNAs in rat and guinea pig brain: distribution and effects of neurotoxic lesions. J Comp Neurol 484:418-439.

Waeber C, Sebben M, Grossman C, Javoy-Agid F, Bockaert J, Dumuis BJ (1993) $\left[{ }^{3} \mathrm{H}\right]$-GR113808 labels $5-\mathrm{HT}_{4}$ receptors in the human and guinea-pig brain. NeuroReport 4:1239-1242.

Waeber C, Sebben M, Nieoullon A, Bockaert J, Dumuis A (1994) Regional distribution and ontogeny of $5-\mathrm{HT}_{4}$ binding sites in rodent brain. Neuropharmacology 33:527-541.

Waeber C, Sebben M, Bockaert J, Dumuis A (1996) Regional distribution and ontogeny of $5-\mathrm{HT}_{4}$ binding sites in rat brain. Behav Brain Res 73:259-262.

Wang S-J, Chen L-L, Gean P-W (1999) Cross-modulation of synaptic plasticity by $\beta$-adrenergic and $5-\mathrm{HT}_{1 \mathrm{~A}}$ receptors in the rat basolateral amygdala. J Neurosci 19:570-577.

Yokoyama M, Suzuki E, Sato T, Maruta S, Watanabe S, Miyaoka H (2005) Amygdalic levels of dopamine and serotonin rise upon exposure to conditioned fear stress without elevation of glutamate. Neurosci Lett 379:37-41. 